\title{
EXPERIÊNCIA DE LEITURA COM O GÊNERO LITERÁRIO CONTO EM SALA DE AULA COM BASE NO PLANEJAMENTO PEDAGÓGICO ${ }^{\text {Iil }}$
}

\author{
Maria Lúcia Pessoa Sampaio \\ Doutora em Educação pela UFRN
}

RESUMO: Esse estudo assume a interface entre leitura e planejamento pedagógico. Objetiva-se, aqui, focalizar as práticas de planejamento de leitura, voltadas para a implementação do gênero literário "conto" em sala de aula. Das cinco sessões de leitura de contos literários (transcritas e gravadas) que se constituíram corpus da pesquisa-ação, elegeu-se, para esta análise a quarta sessão. Os resultados apontam para a importância do planejamento, que desempenha a função mediadora, na medida em que ao plano foi atribuído o estatuto de instrumentalizar a ação docente, servindo à professora como guia para discussão do texto, ora atribuindo uma função utilitária, ora dando significado ao discurso literário, como instância provedora de prazer.

PALAVRAS-CHAVE: Leitura; planejamento pedagógico; conto literário.

ABSTRACT: This study presupposes an interface between reading and pedagogical planning. The aim of such a research is putting practices of reading planning in focus related to implementation of the literary genre "short story" in classroom. We saw five classes in which the teacher approached short stories (recorded and after that transcribed). Among these five sections that form the corpus in this action research, we chose just one them to the analysis, that one proposed in the forth section. The results show the importance of planning that develops a mediating role, in the sense that it serves to support teacher's actions. In addition, the pedagogical planning works as a guide to text discussion, attributing it a utility function and giving meaning to literary discourse as a way of providing pleasure.

KEYWORDS: Reading; pedagogical planning; short story.

\section{Introdução}

Esse trabalho é resultante de uma investigação composta de três etapas, embora, focaliza-se, aqui, a terceira (2002/2005) na qual desenvolveu-se pesquisa-ação participativa. Têm-se como participantes professores de Língua Portuguesa ( $3^{\circ}$ ciclo) e outros segmentos de uma escola pública de Pau dos Ferros - RN, tendo-se como foco de análise para este estudo, as práticas de planejamento de leitura, voltando-se mais especificamente, para a análise da implementação do planejamento pedagógico do gênero conto em sala de aula.

A análise proposta tem como fio condutor a tese de doutorado, que versa sobre "a função do planejamento na aula de leitura de textos literários" (SAMPAIO, 2005), defendida na Universidade Federal do Rio Grande do Norte (PPGEd/UFRN). Das cinco sessões de leitura de contos literários, transcritas e gravadas, constituindo-se, portanto, parte do corpus da pesquisa-ação, elegeuse, para este trabalho a primeira sessão (referente ao $13^{0}$ encontro da pesquisaação participativa), desenvolvida pela professora Karla, aos 07/11/2002, numa turma de $5^{\text {a }}$ série ( $3^{\text {o }}$ ciclo) do ensino fundamental. A partir dos dados da sessão de leitura do conto "Tampinha" de Ângela Lago, discute-se, aqui, a atuação da professora e dos aprendizes, diante do trabalho com o conto, enquanto gênero literário, tendo como referência de análise o planejamento 
pedagógico.

Tomam-se, como bases teóricas para essa investigação, os estudos sobre planejamento participativo (VASCONCELOS, 1999; VIANNA, 2000) pautando-se, mais especificamente, pelo planejamento dialógico (PADILHA, 2002). A perspectiva de ensino de língua/leitura adotada orienta-se pela concepção sóciointeracionista da linguagem (BAKHTIN, 1997; VYGOTSKY, 1996; GRAVES \& GRAVES, 1995), enfatizando-se, também, os estudos de Smith (1989). Para o estudo dos gêneros textuais apóia-se em Bronckart (1999), além dos PCNs (1998) enquanto referenciais. A análise envolve, ainda, a Estética da Recepção (JAUSS, 1979; ISER, 1996/1999 e ECO 1994/2003), dada à atuação do leitor e sua interação com o texto.

\section{Aspectos teórico-metodológicos do estudo}

Apresentam-se como conceitos axiais para esta análise, a discussão acerca do planejamento dialógico e de gênero do discurso. No que concerne ao primeiro, apóia-se nas palavras de Padilha (2002, p. 68) ao afirmar que,

O planejamento dialógico é um tipo de planejamento participativo, mas se diferencia deste por uma característica bem marcante, que se refere à criação de mecanismos que viabilizem as consolidações tiradas nos níveis "inferiores" do sistema educacional, com o objetivo de garantir que as decisões tomadas, por exemplo, nas escolas, possam ser apresentadas e defendidas por representantes daquele nível, no nível imediatamente "superior".

Desse conceito, ressalta-se que este comporta a idéia de planejamento não apenas enquanto ação, mas incluindo, principalmente, a participação nas tomadas de decisões dos envolvidos. Considera-se, ainda o fato de que esse tipo de planejamento não dicotomiza a dimensão pedagógica da dimensão administrativa, nem subordina uma à outra.

No contexto da pesquisa, tornou-se evidente que o planejamento dialógico é possível quando há conhecimento específico da escola campo de pesquisa. Nesse caso, os trabalhos anteriormente desenvolvidos no âmbito da escola através de estudos exploratórios ( $1^{\underline{a}}$ etapa), via pesquisa etnográfica ( $2^{\underline{a}}$ etapa) veio demonstrar o caráter do trabalho democrático que a referida escola almeja, especialmente, durante a pesquisa-ação participativa momento em que a mobilização dos seus diferentes segmentos, constituiu-se num dos desafios enfrentados por todos os segmentos escolares.

O segundo conceito axial diz respeito à compreensão que se adota sobre gênero, a partir da seguinte reflexão: por que se defende a noção de gêneros e não de tipos de textos, e, ainda, se é possível relacionar planejamento (dialógico) à noção de gêneros textuais.

A nomeação de gênero de texto ou de gênero do discurso, segundo Bronckart (1999, p. 73-74) tem se manifestado desde a Antiguidade grega até a contemporaneidade. A partir de Bakhtin se traduz uma maior delimitação e estudos acerca das múltiplas produções verbais organizadas, resultando no agrupamento de textos como pertencentes a um determinado gênero, de modo que, atualmente, sua aplicação ao ensino tem sido preocupação de inúmeros pesquisadores.

Para Bronckart (1999, p. 75) o texto é visto como "toda unidade de produção de linguagem situada, acabada e auto-suficiente (do ponto de vista da 
ação ou da comunicação)". Porém, como todo texto se insere em "conjunto de textos" ou em um gênero, o autor esclarece que é por isso que adota "a expressão gênero de texto em vez de gênero de discurso", abandonando, claramente, a noção de tipo de texto, a favor das de gênero de texto e de tipo de discurso (p. 15).

Gênero do discurso é definido por Bakhtin (1997, p. 279) como "tipos estáveis de enunciados", que se caracterizam numa "heterogeneidade de gêneros" orais e escritos e que estão presentes nas diferentes esferas da atividade humana. Esse movimento "comporta um repertório de gêneros do discurso que vai diferenciando-se, ampliando-se á medida que a própria esfera se desenvolve e fica mais complexa (idem)".

Os enunciados de que trata Bakhtin são entendidos como uma forma de utilização de língua tanto na oralidade como na escrita, mantendo-se mutuamente interligados a outros enunciados que pressupõem o papel ativo do "outro" no processo de comunicação. Como explica esse mesmo autor: "aprender a falar é aprender a estruturar enunciados (porque falamos por enunciados e não por orações isoladas e, mesmo ainda, é óbvio, por palavras isoladas)" (ibid. p 302).

São muitos e variados os gêneros discursivos, e o surgimento de cada um deles depende das condições específicas de uma dada comunicação, podendo ser apresentados, conforme Bakhtin, em dois grandes grupos: "os gêneros de discurso primário (simples)", que estão presentes nos tipos de diálogo oral e espontâneo: como a linguagem utilizada nas reuniões sociais, entre outras situações; e, os "gêneros do discurso secundário (complexos)", aparecem nas comunicações mais evoluídas, principalmente escritas, que podem ser vistos nos discursos "literários, científicos e ideológicos". A língua escrita, na opinião do autor, de forma ampliada, comporta ou absorve todos os gêneros em cada momento de seu desenvolvimento.

Enfim, convém, aqui ressaltar, a relação do planejamento com a noção de gêneros do discurso: compreende-se que a ação de planejar, enquanto atividade eminentemente cognitiva e de natureza discursiva apresenta-se como um modo de operar dialógico. O planejamento pedagógico pode ser visto como um instrumento que corporifica um conjunto de intenções, não apenas pedagógicas, mas também políticas, como resultado das diferentes interações humanas. E, assim como toda atividade humana, dependerá também do seu contexto e de suas condições de produção. Isso não se dá no isolamento, ao contrário, tem uma relação direta com o auditório social a que se dirige, portanto, é nessa perspectiva que se entende o caráter dialógico do planejamento.

Nesse sentido, como "todo texto tem um sujeito, um autor (que fala, escreve)" é importante que se atente para o fato de que ao registrarem suas propostas de trabalho nos planos de aulas, os professores têm possíveis "destinatários" que, conforme BAKHTIN (1997, p. 320-321), poderiam ser: “[...] o parceiro e interlocutor direto do diálogo da vida cotidiana, pode ser o conjunto diferenciado de especialistas em alguma área especializada [...] dos subalternos, dos chefes, dos superiores, dos próximos, dos estranhos, etc.; pode até ser de modo absolutamente indeterminado, o outro não concretizado [...]".

Partindo do princípio de que o "objeto de ensino e, portanto, de aprendizagem são os conhecimentos lingüísticos e discursivos com os quais o sujeito opera ao participar das práticas sociais mediadas pela linguagem" (BRASIL, 1998, p. 12) é que os PCNs defendem o trabalho com gêneros textuais.

Tendo o texto como unidade básica para o ensino de língua materna, o referido documento sugere, que na seleção de textos orais e escritos, contemple-se o texto literário, uma vez que este "ultrapassa e transgride para 
constituir outra mediação de sentidos entre o sujeito e o mundo, entre a imagem e o objeto, mediação que autoriza a ficção e a reinterpretação do mundo atual e dos mundos possíveis" (p. 17). E dentre os gêneros privilegiados para a prática de escuta e leitura de textos, está o gênero literário conto, enquanto um dos aspectos a ser trabalhado da linguagem escrita.

\section{O conto "Tampinha”, de Ângela Lago}

Esse texto faz parte do livro "Historinhas pescadas". O próprio título do livro remete a uma variedade de narrativas selecionadas e designadas contos, cuja coletânea é apresentada por Marisa Lajolo (2001). São dez, no total, escritos por diferentes escritores brasileiros de diferentes épocas e regiões, como ressaltado na apresentação. O referido livro faz parte da coleção "Literatura em minha casa - Volume 2", enviada pelo MEC/FNDE para as crianças de $5^{\text {a }}$ série, através do programa Biblioteca da Escola, com vistas ao incentivo à leitura.

A seleção do conto "Tampinha" para as três sessões de leitura, nas quais este foi trabalhado, foi feita pelos participantes durante o segundo momento da pesquisa, o qual foi destinado, inicialmente, às sessões de leitura realizadas com os professores, e, depois, escolhidos pelas professoras-participantes entre os seis selecionados para o planejamento da referida sessão.

A justificativa apresentada pelos participantes para e escolha desse conto, como registrado na resenha do plano dessa sessão, é que este focaliza "a autoestima, mostrando que é possível quebrar obstáculos" (cf. registro do plano). Apoiando-se na lingüística textual, os professores vêem nas atividades propiciadas pela leitura do referido conto diversificadas estratégias de trabalharem a oralidade e a escrita no âmbito da sala de aula, com vistas à produção de sentido.

Partindo de um conceito de leitura mais abrangente do que a mera decodificação de palavras e sabendo-se que é a prática pedagógica adotada que orienta o professor na escolha de determinada estratégia de trabalho, é que se postula, aqui, o ato de ler enquanto atividade de atribuição de sentido, excluindo-se a possibilidade de uma atividade mecânica ou mera emissão de voz.

É com base na relação (oral/escrito), desencadeada pela mediação do professor, bem como ao estabelecer ponte com a semântica propiciada pelo texto, que o trabalho com a literatura é entendido enquanto experiência humana que envolve tanto a afetividade, quanto o cognitivo e o social.

Quanto à estrutura narrativa do referido conto, este evoca no leitor a lembrança dos contos de fadas, ao ser introduzido com "Era uma vez..."; no entanto, a "economia dos meios narrativos" utilizados pela contista lhe confere inserir-se na "evolução do modo tradicional para o modo moderno de narrar", através de uma "mudança de técnica", mas não de sua "estrutura" (GOTLIB, 1999).

Calvino (2000) ao discutir a "rapidez", enquanto uma dos valores a ser considerados na literatura para esse milênio afirma que o segredo na economia da narrativa está no fato de que "os acontecimentos, independentemente de sua duração, se tornam punctiformes, interligados por segmentos retilíneos, num desenho em zigue-zague que corresponde a um movimento ininterrupto" (p. 48)

Para Eco (2002, p. 15 -16 e 34) a expressão "Era uma vez..." significa que o texto está sinalizando para a escolha do seu próprio leitor-modelo, que pode ser uma criança ou alguém disposto a aceitar as regras estabelecidas no acordo ficcional. Aceitar tacitamente esse acordo pressupõe que o leitor saiba que o 
que está sendo narrado é uma história imaginária, o que não significa que o escritor está mentindo; ou seja, ao entrar no jogo da ficção o leitor-modelo definido pelo autor como "alguém que está ansioso para jogar", finge que o narrado de fato aconteceu, até porque "o texto é uma máquina preguiçosa que espera muita colaboração da parte do leitor."

O conto apresenta três personagens, sendo Tampinha a principal. Através destes, a autora explora relações e conflito de valores. O conto amplia e enriquece a visão da realidade de um modo específico, peculiar, permitindo ao leitor a vivência intensa e, ao mesmo tempo, a contemplação crítica das condições e possibilidades humanas.

Por meio da protagonista Tampinha, na sua condição de transgressora, comporta tamanha teimosia que lhe permite avançar no sentido de vencer obstáculos, apesar do seu tamanho; o conto suscita a sensibilidade do leitor para a problemática central do texto, que é a resolução de problemas por parte dos personagens, o que faz com que mais uma vez sua estruturação se aproxime do conto de fadas, embora muito se assemelhe ao mito dos heróis.

Dentre as várias características da heroína Tampinha têm-se a esperteza, associada a uma certa magia, que, como um anjo da guarda, ajuda a protagonista a se dar sempre bem. A passagem de Tampinha pelas águas do rio "no seu barquinho de papel, com uma agulha servindo de espada, uma colherzinha de café como remo e a pimenta dependurada no pescoço" (LAGO, 2001) determina o rito de iniciação, ou de passagem no seu sentido pleno, marcando a busca da aventura que representa a ruptura do passado, a infância, em relação ao futuro, a maturidade da heroína.

A ludicidade do texto instaurada pelo jogo ficcional provoca o leitor exigindo deste a sua participação à medida que através da estruturação cumulativa do conto este assume caráter de previsibilidade, apostando no equívoco (erro) que se transforma sempre em acerto. É nesse aspecto que se justifica a importância do papel que exerce a literatura para a criança; em virtude da sua riqueza simbólica, que conforme Amarilha (1997, p. 73) torna "acessível ao leitor experiências imaginárias que sejam catalisadoras dos problemas do desenvolvimento humano e assim proporcionar autoconfiança sobre o seu próprio crescimento"

\section{O encontro dos alunos com "Tampinha" em sala de aula}

Pretende-se, aqui, analisar a atuação da professora-participante Karla. Discute-se, portanto, a função atribuída ao planejamento na sessão destacada tendo-o como referência de análise do processo de ensino-aprendizagem.

Levando-se em consideração que o objetivo geral do plano da sessão era "compreender as especificidades do conto literário, com vistas à apreciação desse gênero, tendo o professor como modelo de leitor" e, como objetivo específico "incentivar o aluno para a prática de reconto (oral e escrito)", é que se abordaram esses pontos com base no registro do referido documento, bem como na transcrição da sessão, acercando-se da efetiva atuação por parte da professora e, conseqüentemente, dos aprendizes.

Apoiando-se na transcrição dessa sessão, bem como na observação in loco, observou-se que a professora-participante iniciou a aula apresentando a professora-pesquisadora aos alunos e renovando o contrato didático com a turma ao solicitar dos mesmos a participação no decorrer da sessão. Após fazer a chamada dos alunos nominalmente, a professora chamou a atenção destes motivando-os para a aula, como demonstrado a seguir: 
012. Professora Karla - Bom, gente, a nossa aula de hoje vai ser uma aula bastante interessante, certo? Vou colocar aqui prá vocês verem.

013. Aluno - É para escrever?

014. Professora Karla - Não. Por enquanto não, ninguém copie ((a professora divide o quadro ao meio com um risco de giz e nele escreve a data, o nome da escola e da disciplina)). Olhe, hoje nós vamos trabalhar o gênero conto, certo? Quem já ouviu falar sobre o que é conto? ((anotando a palavra conto no quadro)) Quem poderia dizer o que é conto? Hein, gente, vocês já ouviram falar nessa palavra conto?

015. Todos - Já.

Diante da adesão dos alunos à motivação inicial "hoje vai ser uma aula bastante interessante" (Turno 012), a professora Karla traduz nessa frase a satisfação diante da organização de sua aula e com isso põe em evidência o seu plano, alcançando, de antemão, o engajamento dos seus alunos.

Ao anunciar aos alunos que vai anotar algo no quadro, a professora é logo surpreendida com uma pergunta do aluno: "é para escrever?" O que vem demonstrar que copiar no quadro ainda deve ser uma prática escolar muito freqüente, embora seja perceptível que outras práticas alternativas já façam parte do cotidiano dessa turma.

Percebe-se, nesse episódio, que a professora dá início o primeiro aspecto do plano que é a compreensão dos aprendizes acerca do conto, buscando a diferenciação deste em relação a um outro gênero, como demonstrado nos episódios subseqüente:

Episódio 02:

016. Professora Karla - Já o quê? Vanessa!

017. Vanessa - É uma história escrita ou falada.

018. Professora Karla - É uma história escrita ou falada?

019. Outra aluna - É uma narração

020. Professora Karla - É uma narração escrita ou falada; é uma narração, né, só isso que vocês ouviram falar sobre o conto? O conto é diferente de um poema?

021. Alunos - É.

022. Professora Karla - É? Por que o conto é diferente de um poema? Ele disse que o conto não contém versos, não contém rimas, né, e o poema contém?

023. Alunos - Contém.

Nesse episódio, torna-se evidente a pressa da professora em cumprir o plano na medida em que se limita a apresentar e confrontar de forma elementar a diferença entre conto e poema. Apresenta algumas características do conto como personagens, especificando alguns tipos, os fatos, ressaltando que é uma história curta, apresenta tempo e lugar, como enfatizado no episódio seguinte.

Entretanto, ao instigar os alunos sobre o que é um conto, percebem-se conceitos precisos, como ficou evidenciado na voz de Vanessa ao afirmar ser o conto: "uma história escrita ou falada" (Turno 017), mais adiante complementada por um outro aluno, que diz ser um conto "um fato inexistente" (Turno 025 - Episódio 03). Observe-se a condução dessa discussão pela 
professora no próximo episódio:

Episódio 03:

024. Professora Karla - Contém, não é? Então o conto, certo, ele tem as suas características próprias. Quem poderia me dizer uma característica do conto? Pelo menos uma, pelo menos uma...

025. Alunos - É a narração de um fato inexistente.

026. Professora Karla - Olha, ele está dizendo que o conto é um fato inexistente. Quem concorda? Geralmente são histórias criadas, né, mas muitas vezes eles se baseiam a partir de alguém, a partir da história de alguém, certo? Então, o conto se apresenta, vamos falar assim, ele apresenta os fatos, ele apresenta os personagens, eles podem ser, é, narrador, observador, narrador-personagem, vocês sabem qual é essa diferença? Quando é que o narrador é observador, gente? Quando não participa da narrativa, apenas observa. Quando ele é narrador-personagem?

027. Aluno - Quando ele narra e participa

028. Professora Karla - Quando ele narra e participa do conto, da narrativa, certo? Alguém poderia dizer mais alguma característica do conto? Geralmente o conto, ele não é uma história muito longa, certo? Ele é uma história, é com base só no essencial, não se estende muito. Ele apresenta sempre o lugar. Alguém tem mais alguma pergunta a fazer sobre o conto? Alguma coisa a falar sobre o conto? Ficou claro o que é um conto? Hein, gente, vocês têm alguma pergunta a fazer sobre o conto? Hein, gente, vocês entenderam o que é o conto?

029. Alunos - Entendemos.

030. Professora Karla - Existe diferença entre o conto e o poema?

031. Aluno - Existe.

032. Professora Karla - Existe, né, já entenderam as características do conto?

033. Aluno - Já.

034. Professora Karla - Já, não é? Olha, o conto ele é uma narrativa que apresenta fatos, personagens e o tempo. Quem são os personagens e o tempo? Quem são os personagens? São as pessoas, né, que fazem, pessoas, animais, dependendo de como seja o conto, que fazem parte da história, da narrativa. Olha, hoje eu vou ler aqui para vocês, eu vou ler um conto aqui para vocês, certo? Eu vou ler, primeiro, eu vou mostrar, apresentar o título, certo? Para ver o que vocês acham sobre o que pode falar esse conto. Olha, se vocês vissem um conto com o título Tampinha. Tampinha ((escrevendo no quadro)) O que sugere a vocês essa palavra Tampinha? Hein, gente? Tampinha! Tampinha o que sugere para vocês?

035. Alunos - Personagem?

Embora a professora Karla admita ser o conto "histórias criadas", esta rebate o aluno ao afirmar que "muitas vezes eles [os contos] se baseiam a partir [...] da história de alguém" (Turno 026 - Episódio 03), o que vem desconsiderar o fato de que há três acepções para a palavra conto, conforme Gotlib (1998), o qual pode ser considerado como relato de um acontecimento; a narração oral ou escrita de um acontecimento falso e/ou fábula que se conta às crianças para diverti-las.

Em se tratando do conto literário, a exemplo do utilizado nessa sessão, o critério de "invenção" é o principal a ser considerado, uma vez que, na história 
do conto, principalmente na sua passagem da oralidade para escrita, os recursos criativos foram os mais utilizados (GOTLIB, 1999). Conforme Bosi (1997) "a invenção do contista se faz pelo achamento (invenire = achar, inventar) de uma situação que atraia, mediante um ou mais pontos de vista, de espaço e tempo, personagens e tramas". Conclui esse mesmo autor, que a escolha do universo literário, feita pelo contista, não é aleatória ou inocente como às vezes se supõe. A esse respeito, Calvino (2000) é enfático ao afirmar: "Estou convencido de que escrever prosa em nada difere do escrever poesia; em ambos os casos, trata-se da busca de uma expressão necessária, única, densa, concisa, memorável” (p. 61).

No episódio destacado, a professora apresenta as características do conto, a partir dos conhecimentos prévios dos alunos; entretanto, não há expansão dessas respostas. Essa ausência ocorre em dois momentos distintos e subseqüentes: primeiro, quando a professora discute as diferenças entre os personagens e tipos de narrador (Turnos 026 a 028) e, segundo, ao diferenciar conto e poema (Turno 030).

No primeiro caso, a professora Karla não diferencia os personagens dos tipos de narradores, uma vez que os personagens são os responsáveis pela ação, cuja participação no enredo é que determina seus papéis como: "protagonista” (principal personagem), "antagonista” (oposto ao protagonista) e "secundários" (com menor participação na história); já os narradores exercem o papel de estruturar a história, os quais podem aparecer em "primeira pessoa" ou "narrador personagem", como exemplificado pelo aluno (Turno 027) "quando ele narra e participa", e na "terceira pessoa" ou "narrador observador", como dito pela professora "quando não participa da narrativa, apenas observa" (Turno 028).

O narrador ainda pode ser "onipresente" ao marcar presença em todos os lugares onde ocorrem os fatos, ou "onisciente", quando demonstra saber tudo sobre a história. A atuação das personagens no enredo é relatada pelo narrador que pode participar ou não da ação. Ou seja, as ações que envolvem o conto são apresentadas ao leitor através dos discursos focalizados pela voz do narrador. Conforme Eco (2002, p. 19) os livros escritos na primeira pessoa podem levar o leitor ingênuo a pensar que o “eu” do texto é o autor. Não é, evidentemente; é o narrador, a voz que narra [...] não é necessariamente a do autor".

No caso da personagem principal do conto, seu desempenho no enredo lhe garante a condição de protagonista, com características próprias de um herói mitológico, pois em busca de sua maturidade Tampinha demonstra em sua trajetória de heroína que tem na luta seu objetivo maior, o bem comum de sua coletividade.

Quanto à narração, pode-se afirmar que este conto se caracteriza por apresentar um "narrador observador", sendo "onipresente" no decorrer do enredo. Esses elementos poderiam ter sido analisados, mais tarde, no decorrer das discussões do conto Tampinha, como apresentado no episódio 09. Ao instigar os alunos, a professora Karla sugere: "Certo, bem, vocês têm alguma coisa para perguntar, ou para colocar sobre esse conto? Ficou claro pra vocês o que é um conto? Ficou? Ficou claro pra vocês as características do conto? Olha, o conto tem que ter os fatos, tem que ter o lugar, os personagens, tem que ter o enredo. O que é enredo? É a trama em si, não é?” (Turno 154). Nesse caso, a professora atenta para um conceito de enredo, aproximando-o das discussões feitas por Mesquita (1994, p. 12-21), que, assim como a professora, admite que este pode ser chamado de trama, intriga, como também o caracteriza "como a própria estrutura da narrativa", compreendendo "todo o plano da ação, das transformações das situações que se sucedem, na ordem/desordem em que as 
apresenta o discurso que narra”, de modo que este se manifesta, segundo essa mesma autora, apenas na narrativa de ficção em prosa.

No segundo caso, ao interrogar sobre a diferenciação do conto e do poema (Turno 030) os alunos respondem: "existe" (Turno 031), de modo que a resposta parece satisfazer à professora: “existe, né”, inserindo uma nova pergunta: "já entenderam as características do conto?” (Turno 032). Os alunos, por sua vez, respondem "já" (Turno 033). Observa-se, entretanto, que os dados não confirmam se os alunos, de fato, compreenderam essa diferença e se para eles estão claras as características do conto, pois, para isso, seria necessário que a professora expandisse essas respostas, solicitando aos alunos que especificassem qual a diferença entre os gêneros sugeridos.

A professora prossegue sua aula sem apresentar o livro, sem explorar sua capa, passando ao ponto seguinte do plano, que é levantar as previsões a partir do título do texto como se observa no turno 034. A discussão sobre as especificidades do conto enquanto gênero torna-se incompleta, dada a descaracterização pela professora da sua função discursiva. O que se observa no episódio destacado é que a professora Karla se limita a apresentar a estrutura do conto, ou seja, apenas explora sua modalidade retórica imbuída no aspecto textual da composição deste que é a narração. Reconhecer o conto como gênero exigiria, da professora e dos alunos, múltiplos conhecimentos não apenas acerca da sua organização, mas, sobretudo, da função comunicativa deste em relação a outros já trabalhados.

A dificuldade ao trabalhar com gêneros textuais já havia sido detectada durante pesquisa anterior (SAMPAIO, 2000) e ainda permanece em decorrência do não aprofundamento dos participantes acerca do assunto, inclusive da professora-participante. Considera-se, ainda, o fato de que essa mesma dificuldade também se presentifique nas demais professoras, até porque, no período de formação inicial das mesmas, a discussão inerente a gênero textual não fazia parte da grade curricular nos cursos de graduação nem tampouco com a intensidade das discussões atuais. Não obstante, durante o estudo (momento de fundamentação teórica da pesquisa - 5o encontro da pesquisa), a maioria dos participantes declarou não ter realizado a leitura prévia dos textos acerca dos gêneros, requisito básico para adentrar nessa discussão, resultando o estudo, naquela ocasião, numa exposição dialogada da professora-pesquisadora com os participantes.

Os diálogos subseqüentes a esse episódio vêm confirmar a não entrada da professora na estrutura profunda do texto. Para Smith (1991, p. 42) a estrutura profunda do texto está intimamente relacionada à atribuição de significados pelo leitor, no entanto a professora passou a focalizar apenas a estrutura aparente (informação visual da linguagem escrita) da história: personagens, tempo, lugar, fatos, embora se considerem fundamentais os aspectos em destaque e de extrema importância serem abordados em conseqüência do trabalho com gênero textual. Compreende-se que o reconhecimento de aspectos estruturais do texto e da sua função social, ajudaria aos alunos a compreender o funcionamento da linguagem e das práticas sócio-culturais.

$\mathrm{Na}$ observação das previsões a partir do título, com foco numa leitura mais linear os alunos demonstraram clareza acerca da passagem do ficcional para o real, como demonstrado no episódio seguinte:

Episódio 04:

036. Professora Karla - Certo. Tampinha é personagem. Mas você acha que esse conto vai falar sobre o quê? 
037. Alunos - Uma menina danada

038. Professora Karla - Uma menina danada, o que mais? Quem poderia dizer?

039. Alunos - Uma criança pequena.

040. Professora Karla - Uma criança pequena. Que mais? Quem mais poderia sugerir alguma coisa.

041. Alunos - Uma criança esperta.

042. Professora Karla - Uma criança esperta. Vamos gente, esse título aí, Tampinha, dá a entender que fala sobre o quê? Vocês acham que Tampinha é o nome de uma criança?

043. Alunos - Não, sim.

044. Professora Karla - Não ou sim?

045. Alunos - Não.

046. Professora Karla - E vocês acham que é o quê?

047. Alunos - O apelido.

048. Professora Karla - O apelido. Mas você acha que esse conto, esse título vai falar sobre o quê?

O episódio em análise é marcado pelo momento em que a professora Karla focaliza a previsão dos alunos em relação ao texto, tendo como apoio seu título "Tampinha". Para Smith (1991, p. 34 e 202) a previsão é necessária, pois é o "núcleo da leitura", na medida em que traz significado ao texto e além de eliminar alternativas improváveis, propicia a "projeção de possibilidades" pelo leitor. Para esse autor, as previsões podem ser "globais", relacionadas a uma visão geral do texto, e as "focais", as quais podem ser influenciadas pelas globais, embora se detenha nas especificidades do texto, a partir dos capítulos, parágrafos, sentenças e palavras.

O trabalho com as previsões exige a mediação por parte do professor, com vistas à atribuição de sentido ao texto. No caso do conto Tampinha os alunos conseguem elaborar previsões globais acerca do texto, a partir do seu título (Turno 036). As previsões focais foram marcadas pela insistência da professora para que fossem emitidas pelos alunos a respeito do texto, como demonstrado a partir do turno 042. Os andaimes fornecidos pela professora possibilitaram, assim, a projeção de previsões focais, embora esta se limita em alguns momentos da discussão a repetir as respostas dos alunos.

A pista fornecida pela professora "[...] vocês acham que Tampinha é o nome de uma criança? [...]" (turno 042) provoca o conflito cognitivo na turma: [...] não, sim [...] (turno 043). Com ajuda da professora os alunos concluem que Tampinha não é um nome de uma pessoa, mas um apelido (turno 047). Essa confusão de idéias vem caracterizar o momento vivido por esses alunos que estão numa fase que já demonstram maior conhecimento da realidade. Embora estejam mais voltados para a ação, ainda, valorizam o herói que vence obstáculos.

De um lado, percebe-se que através das experiências pessoais e pensamento racional esses alunos demonstram maior domínio pelas ações abstratas. Porém, como assinala Cunha (1991, p. 100) "mais que conhecer o desenvolvimento infantil, importa conhecer a criança, sua história, suas experiências e ligações com o livro". Por isso, uma das preocupações no momento da escolha dos textos literários que seriam trabalhados nas sessões de leitura é que os professores, enquanto conhecedores dos seus alunos, de seus interesses, definissem quais contos seriam destinados a determinadas turmas. Por outro lado, os alunos apresentaram nítida capacidade de adentrarem no jogo ficcional, dada à compreensão de que o conto não se refere somente ao acontecido, embora "todo o mundo ficcional se apóia 
parasiticamente no mundo real, que toma por seu pano de fundo [...]. Na verdade, espera-se que os autores não só tomem o mundo real por pano de fundo de sua história, como ainda intervenham constantemente para informar aos leitores os vários aspectos do mundo real que eles talvez desconheçam" (Eco, 2002, p.99-100).

O aspecto ficcional-real não é visível pela professora, nesse momento, embora mais tarde (Turno 077) ela possibilite a entrada dos alunos no jogo ficcional propiciado pelo texto, ao perguntar: "Qual era o nome dessa menina?" $\mathrm{E}$ os alunos respondem: "Tampinha". Noutro momento (Turno 096), mais uma vez o real-ficcional é abordado, na medida em que a professora pergunta: “Gente, vocês acham que um conto desses acontece na vida real?" E os alunos respondem sem nenhuma dúvida: "não", "é impossível” acontecer.

Dando continuidade à aula, fazendo o levantamento de previsões pelos alunos, a professora Karla anuncia a leitura do conto e, valendo-se do plano, lembra de apresentar o livro e a autora do conto. Após a leitura em voz alta, com boa entonação e articulação das palavras pela professora e, por sugestão própria uma aluna se propôs a ler novamente o conto, obtendo total atenção por parte dos aprendizes. Como consta no plano da sessão, a professora Karla inicia a pós-leitura, cujo objetivo é retomar as previsões em relação ao texto para confirmá-las (ou não), como mostra o episódio a seguir:

Episódio 05:

067. Professora Karla - Tem alguma relação entre o que vocês sugeriram sobre o que ia falar o conto a partir do nome?

068. Aluno - Não.

069. Professora Karla - Eu apresentei, nós apresentamos o nome, eu perguntei sobre o quê vocês achavam que ia falar o texto. Quem lembra o que foi dito?

070. Aluno - Que falava sobre uma menina.

071. Professora Karla - Alguém disse que falava sobre menina, né?

072. Aluno - Que falava sobre uma tampa de garrafa.

073. Professora Karla - Outros disseram que falava sobre uma tampa de garrafa, outros disseram que falava sobre um menino sapeca, não foi?

074. Alunos - Foi.

075. Professora Karla - Pois, olhe, falava sobre o quê? Uma menina muito?

076. Alunos e Cristina - Pequena, né?

077. Professora Karla - Qual era o nome dessa menina?

078. Alunos - Tampinha

079. Professora Karla - Tampinha. Olhe, ela disse que falava sobre uma tampa de garrafa. Lembra o que Kalline disse? Ele ((referindo-se a outro aluno)) disse que falava sobre uma menina sapeca. Se nós juntarmos, de qualquer forma, houve uma previsão da leitura, né? Claro que vocês não disseram sobre o desenrolar do conto, mas também seria impossível, né?.

Ao confirmar as previsões dos alunos, percebe-se que a professora Karla insiste que a previsão sobre a personagem fosse confirmada, embora em sua fala chame atenção para o fato de que previsão não é adivinhação (cf. SMITH, 1991), ao comentar: "de qualquer forma houve uma previsão da leitura, né, claro que vocês não disseram sobre o desenrolar do conto, mas também seria impossível, né?" (Turno 079).

Ainda nesse episódio torna-se evidente a ausência do fornecimento de 
andaimes pedagógicos oportunos, uma vez que a professora Karla conduz a pósleitura perguntando qual a parte do texto que os alunos mais gostaram, sem problematizar o porquê, cuja dinâmica de repetição das falas dos alunos demonstrou-se insuficiente para sustentação da discussão, o que vem surpreender a própria professora: "Valha, achei que vocês iam falar tanta coisa!" (Turno 081) o que parece desencadear a leitura e ao mesmo tempo desafiar os alunos para adentrarem no texto, conforme se observa no enunciado a seguir:

\section{Episódio 06:}

081. Professora Karla - Olha, ela achou interessante a parte que ela não soube dizer as palavras mágicas corretas. Quem mais? Valha, achei que vocês iam falar tanta coisa! Diga.

082 . Aluno - Achei interessante quando que ela foi crescendo conforme ia comendo as frutas.

083. Professora Karla - Quem mais gostaria de falar?

084. Vanessa - Achei interessante porque ela, pequenininha desse jeito, vai naquela árvore! Achei ela muito pequena e corajosa pro tamanho dela.

085. Aluno - Quando ela estava maior e que conseguia voar.

086 . Professora Karla - Quando ela estava maior, mesmo assim conseguia voar. Quem mais gostaria de falar?

087. Aluno - Na hora da onça.

088. Professora Karla - Na hora da onça, né?

089. Aluno - Hei [inaudível].

090. Professora Karla - Na hora da serpente. Quem mais gostaria de falar?

091. Aluna - Quando ela foi viajar, aí ela fez um barquinho de papel, né, [inaudível].

092. Professora Karla - Ela disse que foi na hora que ela foi viajar no barquinho de papel e que a espada era uma agulha.

093. Aluna - Na hora que o curupira apareceu.

094. Professora Karla - Na hora em que o curupira apareceu.

095. Aluno - [inaudível].

096. Professora Karla - Olha, ele disse que aí há persistência, né? Ela só insistindo pra ir e a avó sem querer deixar, e a avó sem querer deixar, até que a avó resolver liberá-la, né? Gente, vocês acham que um conto desses acontece na vida real?

Como demonstrado nesse episódio, dada a não problematização na mediação da professora os alunos respondem e não há uma expansão das respostas. Inclusive, como repetido pela professora (Turno 096). A resposta do aluno aponta para a função principal do discurso do texto, que é convencer o leitor da importância da persistência diante dos obstáculos; no entanto, somente posteriormente a professora faz a retomada desse aspecto. Já as falas dos alunos apontam para o ponto culminante da história, ou seja, estes se detêm ao clímax, que coincide com as ações, conflitos resolvidos pela protagonista Tampinha, o que lhe confere a condição de heroína da história.

Ainda nesse turno, a professora continua seguindo o planejado, embora se perceba que esta deixa de cumprir um aspecto abordado no plano que é "quem já havia lido a história". Esse aspecto vem contemplar a flexibilidade do planejamento, cujo redimensionamento deste pela professora traz à tona $o$ desconhecimento da história pelos alunos, à medida que estes não conseguiram mostrar efetivamente quem era de fato Tampinha. 
A professora passa, então, para um outro ponto, embora não conste no plano, que é solicitar aos alunos o "exemplo que o conto dar" (Turno 096), quando estes haviam respondido que era impossível um conto dessa natureza acontecer na vida real (relação ficção-realidade). A professora pergunta: "Não, né? Mas, qual é o exemplo que esse conto quer dar?" Nessa mesma perspectiva (Turno 113): “Será que nós não temos um exemplo para contar?" E, mais adiante: "Qual a lição que esse conto deixou para vocês gente? Nem uma mensagem?" (Turno 122). Esse episódio vem comprovar mais uma vez a prática dos professores dessa escola em trabalhar textos que sejam portadores de lição de vida, como ocorre nas fábulas, parábolas, ou seja, o texto literário passa a ser um pretexto para moralizar os alunos com a intenção de torná-los dóceis.

Entende-se que a arte literária passa a exercer em perguntas como essas uma função utilitária, ou seja, o valor atribuído à literatura pela professora, nesse caso, é que aquela pode ser vista como algo a promover valores sociais, morais, éticos, os quais devem ser aceitos pelos alunos. Aponta, ainda, para uma concepção de linguagem como transmissora de informações, reduzindo, assim, o espaço de interlocução, cujo sentido do texto passa a ser dado e não construído pelos interlocutores (SAMPAIO, 2003, p. 167)

Como os alunos avaliam a solução encontrada pela a avó de Tampinha é o tópico seguinte do plano da sessão. A professora Karla pergunta para os alunos se eles "acham que foi correta a atitude da avó deixar uma menina tão pequena sair?" Há um certo silenciar dos alunos em relação a essa pergunta, de modo que apenas dois deles afirmam que foi uma atitude correta. A pergunta da forma que está elaborada direciona o olhar dos alunos para a problemática do tamanho da personagem, o que parece repassar a estes alunos uma certa censura em relação à postura da avó de Tampinha, fato este contestado pela minoria dos alunos. Apesar da discordância do ponto de vista da professora, a maioria prefere calar, o que faz prevalecer a autoridade do professor ao emitir um ponto de vista, mesmo que de forma implícita.

Outro aspecto a ser explorado no plano é "tentar relacionar o texto à vida dos alunos". Porém, essa questão é conduzida pela professora em consonância com a subseqüente: a discussão "do foco central do texto que é a possibilidade de superação de obstáculos" (Turno 111). A professora redimensiona o planejamento ao incluir uma nova questão na pós-leitura, ao expandir a idéia do texto de como a avó curava as pessoas com ervas. Assim, demonstrando ser conhecedora da realidade dos seus alunos, esta expande essa questão, com vistas a relacionar o texto à vida das crianças, como se observa no episódio seguinte:

\section{Episódio 07:}

111. Professora Karla - Oi, já? Quem gostaria de falar? Porque Tampinha teve que vencer vários obstáculos para conseguir o remédio para o moço bonito, não foi? E vocês já passaram por alguma dificuldade, tiveram que vencer algum problema? Quem gostaria de falar? Ou conhece alguém que já passou por problema, é, e venceu, superou os obstáculos? Hein, gente? Um irmão, o pai, a mãe quem gostaria de contar? Será que uma pessoa que tem uma doença, né, e consegue, luta, luta, luta pra vencer aquele problema, ela venceu um obstáculo?

112. Alunos - Venceu.

113. Professora Karla - Venceu, né? E precisa do quê? Conseguem, né? Será que nós não temos nem um exemplo para contar? Diga aí. 
114. Vanessa - Um tio do meu pai. Um tio do meu pai, né, tio segundo ele estava no princípio de um câncer, né, um câncer na cabeça, aí como estava no princípio, ele foi para Brasília fez um tratamento e ficou curado.

115. Professora Karla - Quem mais gostaria de contar? Vocês, olha aqui no texto, né, a avó precisava da flor pra fazer um chá. Vocês acreditam que os chás podem curar?

116. Aluno - Acredito.

117. Fabíola - Pode sim.

118. Professora Karla - Como é, Fabíola?

119. Fabíola - [inaudível].

120 . Professora Karla - Quem mais? Vocês teriam algum conhecimento de alguém que ficou melhor por causa de um chá? Diga, Thiago.

121. Tiago - Minha mãe, ela estava bem gripada, bem mesmo, aí fez um chá não sei do quê e melhorou.

Além de explorar a relação texto-vida, vê-se que, ainda nesse episódio há uma retomada do texto pela professora, quando diz "[...] olha aqui no texto, né [...]" (Turno 115). Ao desafiar os alunos para a discussão do foco central do texto (Turno 111 - 114), a professora fez questão de chamar a atenção deles novamente para o texto quando diz: "então no texto mostra que Tampinha, né", (turno 130), como destacado, posteriormente, no Episódio 08. Esses aspectos vêm demonstrar a valorização do texto, enquanto material concreto, e até mesmo justifica a sua presença na sala de aula, recebendo, portanto, um privilégio condizente com a posição que este detém na sociedade e na cultura letrada.

Como apresentado no episódio, em destaque, a professora incentivou os alunos, apoiando suas falas, de modo que conseguiu destes relatos pessoais sobre a superação de obstáculos por eles vivenciados (Turno 114 e 121), contemplando, portanto, a relação texto-vida evidenciada no plano.

A professora Karla redefiniu o planejado ao desafiar os alunos a identificar a seqüência lógica das idéias do texto, como mostra o episódio seguinte:

Episódio 08:

130. Professora Karla - Olha, gente! Então, o texto, né, mostra que Tampinha, né, ela passou o conto inteiro, todo o desenrolar do conto, ela passou superando obstáculos, né, qual foi o primeiro obstáculo que ela teve que vencer?

131. Aluno - A serpente.

132. Professora Karla - A serpente, né, ela demonstrou o quê quando teve que vencer?

133. Aluno - A coragem.

134. Professora Karla - A coragem, não é? Qual foi o segundo obstáculo?

135. Alunos - A onça.

136. Professora Karla - A onça, não é? E o terceiro?

137. Alunos - O curupira.

138. Tereza Cristina - Curupira não é? Então será que nós já seríamos capaz de dizer quem são os personagens do texto? Do conto?

139. Alunos - Já. 
140. Professora Karla - Olha gente vale salientar que o conto ele é uma das narrativas que geralmente ele não tem muitas personagens, certo? Mas vamos ver aqui quem são os personagens desse conto?

141. Alunos - A cobra, a onça, o curupira, Tampinha, a avó, o Bonito.

Através desse exercício, a professora desencadeou a identificação das características do conto, iniciando pelos personagens, enfatizando a superação de obstáculos, agora vivenciados pela protagonista. Os alunos apresentaram os personagens, de modo geral, nessa ordem (cobra, onça, curupira, Tampinha, avó, e Bonito), sem destacar os principais e secundários do conto e sem que professora chamasse a atenção nesse sentido (Turnos 131 - 137). Contudo, essa estratégia possibilitou aos alunos o reconhecimento dos personagens como demonstrado no turno 141.

Em seguida, a professora Karla passa a identificar, com os alunos, o tempo por ela entendido como cronológico. No entanto, o conto Tampinha apresenta uma seqüência temporal confusa, cujas ligações temporais na voz do narrador "talvez queira nos fazer perder nossa noção de tempo, mas nos estimula a reconstituir a seqüência exata dos acontecimentos" (ECO, 2002, p. 45). Inicia-se o conto com a apresentação de "uma menina tão pequena que, cada vez que espirravam por perto, ela voava" (LAGO, 2001); depois, tem-se a informação de que após comer um fruto Tampinha torna-se moça feita. E, para finalizar, o narrador sinaliza a respeito do casamento de Tampinha com o moço Bonito.

O lugar é reconhecido como a floresta, embora não sejam delimitadas, precisamente, na discussão, as categorias de lugar e espaço como aspectos importantes, dada a quantidade de acontecimentos em locais diferentes vividos pela protagonista. O fato em si, a professora tenta discuti-lo em dois momentos distintos (Turnos 144 e 148) sem clareza suficiente para que os alunos o identificassem. O próximo episódio visa a ilustrar essa discussão:

Episódio 09:

142. Professora Karla - Na opinião de vocês, qual é o momento principal desse conto?

143. Aluno - Na hora do curupira.

144. Professora Karla - Ele disse que o momento principal é na hora do curupira. ((atendendo uma pessoa da equipe pedagógica na porta)) Gente, esse conto, olha, como eu disse pra vocês, o conto ele apresenta o tempo, o lugar, apresenta esse conto aqui, ele apresenta o tempo quando esses fatos acontecem?

145. Aluno - O quê?

146. Professora Karla - Apresenta o tempo, deixa claro o tempo?

147. Aluno - Não.

148. Professora Karla - Não, né, a gente só sabe o tempo cronológico, né, em que as coisas foram acontecendo consecutivamente, né? E o lugar? Será que é na cidade?

149. Alunos - Em uma selva.

150. Professora Karla - Numa floresta, certo? Na opinião de vocês, qual é o momento principal desse conto?

151. Aluno - No final.

152. Professora Karla - Ele disse que é no final, quando? Como assim? Explique aí.

153. Aluno - [inaudível].

154. Professora Karla - Certo, bem, vocês têm alguma coisa para 
perguntar, ou para colocar sobre esse conto? Ficou claro pra vocês o que é um conto? Ficou claro pra vocês as características do conto? Olha o conto tem que ter os fatos tem que ter o lugar, os personagens, tem que ter o enredo. O que é o enredo? É a trama em si, não é? Agora quem de vocês seria capaz de recontar o conto? Hein? Olha, eu li, Vanessa leu, nós discutimos, agora eu quero saber quem seria capaz de recontar, ou seja, de contar, vamos ouvir, gente!

\section{Aluna - [inaudível].}

No episódio anterior, percebe-se o esforço da professora em cumprir o plano, à medida que o redimensiona com vistas a pôr em evidência a organização lógica das idéias do conto. Esse redimensionamento evidenciado no turno 142: “[...] qual o momento principal desse conto?" permite ao aluno afirmar: "Na hora do curupira" (Turno 143). No entanto, a interrupção da aula da professora parece dificultar uma mediação consistente nesse momento, que apoiasse a resposta do aluno. Porém, a professora tenta recuperar o fio da discussão elaborando uma nova questão, com vistas a dar continuidade a sessão.

A professora Karla pergunta duas vezes aos alunos (Turnos 142 e 150): "qual o momento principal do conto?" As respostas dos alunos culminam para o desfecho da história, quando dizem: "na hora do curupira" (turno 143) e "no final" (turno 151). Sabe-se que o desfecho da história é marcado pelo momento de resolução dos conflitos, apresentando um final feliz, visto como um dos requisitos essenciais da narrativa para crianças, dado o envolvimento e identificação destas com a história (CUNHA, 1991).

Cumprida a parte de pós-leitura (compreensão oral) do plano da sessão, a professora introduz a atividade de produção oral e escrita. Inicialmente, a professora sugere o reconto oral, como registrado no plano da sessão, de forma que incentiva e encoraja os alunos a recontarem, como apresentado no turno que segue:

Episódio 10:

159. Aparecida - Esse conto fala de uma menina muito pequena e que usava uma tampa na cabeça pra ficar mais pesada. Um dia um rapaz que morava vizinho a ela ficou doente, aí a avó dela precisava ir a floresta pegar a flor da árvore do curupira e Tampinha se ofereceu pra ir [...].

160. Professora Karla - Alguém mais gostaria de recontar? Bom, porque mesmo sendo o mesmo conto, cada pessoa que conta, que reconta, tem uma forma diferente de recontar. Quem mais gostaria? Ninguém mais? Certo. Olha como vocês não querem mais recontar

161. Aluna - ((acenando que queria recontar)).

162 . Professora Karla - É? Pois vamos, você disse que queria recontar?

163. Aluno - Eu queria ler. ((A professora-participante consulta através de aceno, a professora-pesquisadora se ela poderia ler))

164. PP - Já foi lido duas vezes.

165. Professora Karla - É. Se alguém quiser recontar pode, né, Lúcia?

166. PP - É pode.

167. Professora Karla - Vai, você conta da sua maneira pra gente ver o seu nível de entendimento.

168. Aluno - Era uma menina muito pequena. Toda vez que alguém 
espirrava ela voava. Seu nome era Tampinha. É é um dia um rapaz que morava perto da sua casa estava doente e sua avó era quem cuidava daquele povo da região. Então, ela precisava de uma flor da árvore do curupira e ela não tinha ninguém para pegar essa flor. Então Tampinha disse que ia. Aí foi a avó dela disse que ela era muito pequena e não tinha, assim, coragem, condições de pegar, mas ela insistiu, insistiu, até que a avó dela disse que ela podia ir [...].

O episódio anterior ilustra o momento dos recontos orais. Embora no plano da sessão estivesse registrado que apenas um(a) aluno(a) seria convidado(a) a recontar, a professora deixou-os muito à vontade, de modo que quantos quisessem recontar estaria aberta a sessão de reconto. Dois alunos se manifestaram interessados em recontar, sendo que um deles, no caso o último reconto, foi feito com apoio no texto, como notificado pela professora, no episódio seguinte (Turno 169).

Essa estratégia utilizada pela professora vislumbra nesse episódio uma concepção mais aberta da relação professor-aluno, evidenciando um processo dialógico da leitura, no qual o sujeito-leitor se percebe livre para fazê-lo e não pressupõe o ato de ler enquanto um dever a ser cumprido. Ficou evidenciado tanto no momento da leitura quanto na atividade de reconto o efetivo engajamento dos alunos com o texto literário, fato esse presenciado também no decorrer das atividades de pós-leitura.

Na seqüência do plano, é chegado o momento da atividade de produção escrita, que seria desenvolvida através de reconto escrito pelo professor com os alunos ou apenas por estes, em duplas. Entretanto, a professora antecipa seu planejamento, certamente já prevendo o tempo necessário, incluindo logo o que está proposto no plano da sessão, na parte da análise lingüística, que seria propor aos alunos identificar as características encontradas no conto, como personagens, tempo, lugar etc. (Turno 154). A partir daquele momento, a professora encaminha a produção escrita. A professora optou por encaminhar a tarefa em duplas, mas dando liberdade aos alunos que quisessem fazer individualmente. Orienta aos alunos para registrarem seus nomes, turma e turno, sugere que a atividade seja ilustrada. Os alunos desenvolvem a tarefa com capricho e demonstram satisfação em fazê-la. Alguns começam e entregá-la a professora, até que o toque da sirene avisa o encerramento da sessão. Os alunos saem da sala calmamente, despedindo-se da professora.

\section{Conclusão}

Evidenciou-se, no decorrer dessa atividade, a satisfação dos alunos em desenvolvê-la. A professora Karla sugere ainda que as produções poderiam ser ilustradas, visto que alguns alunos demonstraram interesse ao perguntar a professora se poderiam ilustrá-las. A professora sugere como encaminhamento aos alunos seguir as regras básicas de escrita no uso de pontuação, acentuação, entre outros, o que parecia fazer parte do contrato didático com a turma.

Observou-se que era previsível pela professora a não continuidade do trabalho nessa sessão com a análise lingüística como estabelecido no plano. Talvez por isso mesmo a professora não demonstrou nenhuma ansiedade nesse sentido mesmo sendo provocada pela professora-pesquisadora ao perguntar pelo horário do toque de saída.

Com efeito, a parte proposta para análise lingüística não foi contemplada 
durante essa sessão, embora a identificação das características do conto que fazia parte desse momento já houvesse sido explorada pela professora em momento anterior, deixando de ser abordada a "discussão sobre problemas ortográficos e os avanços observados nos alunos" como previsto no plano.

A avaliação seria um outro ponto a ser considerado, bem como a indicação de novas leituras. Porém, o tempo não foi suficiente para que o planejado fosse implementado. Com isso, leva-se a inferir que o planejamento pedagógico, grande parte aqui implementado, desempenha a função mediadora entre as metas pedagógicas almejadas pela professora Karla no processo de ensinoaprendizagem e a efetiva prática docente da professora, na medida em que a este foi atribuído o estatuto de instrumentalizar sua ação docente, servindo-lhe como guia para uma discussão mais consistente sobre o texto, ora atribuindolhe uma função utilitária, ora dando-lhe significado ao discurso literário, enquanto instância provedora de prazer.

\section{Referências}

AMARILHA, Marly. Estão mortas as fadas? Literatura infantil e prática pedagógica. Petrópolis/RJ: Vozes, 1997

ÂNGELO, I. Negócio de menino com menina. In: De conto em conto: antologia de contos. São Paulo: Moderna, 2002.

BAKHTIN, M. Estética da criação verbal. Trad. Maria Ermanita Galvão G. Pereira. São Paulo: Martins Fontes, 1997.

BRASIL. Ministério da Educação e Cultura. Secretaria de Educação Fundamental. Parâmetros curriculares nacionais: terceiro e quarto ciclos do ensino fundamental - língua portuguesa. Brasília, 1998

BRONCKART, J. P. Atividade de linguagem, textos e discursos: por um interacionismo sócio-discursivo. Trad. Anna Rachel Machado, Péricles Cunha. São Paulo: EDUC, 1999.

CALVINO, Italo. Seis propostas para o próximo milênio. 6. reimpressão. Tradução por Ivo Barroso. São Paulo: Companhia das Letras, 2000.

COSTA, Sérgio Roberto. Interação e letramento: uma (re) leitura à luz vygotskiana e bakhtiniana. Juiz de Fora: Ed. UFJF, 2000.

CUNHA, Maria Antonieta A. Literatura infantil: teoria e prática. São Paulo: Ática, 1991.

ECO, U. Seis passeios pelo bosque da ficção. Trad. Hildegard Feist. 6. reimpressão. São Paulo: Companhia das Letras, 2002.

GOTLIB, Nádia Battella. Teoria do conto. 9 ed. São Paulo: Ática, 1999.

GRAVES, M. F.; GRAVES, B. B. A experiência de leitura pro andaime: uma referência flexível para ajudar os estudantes a obter o máximo do texto. USA: UKRA, 1995.

ISER, W. O ato da leitura: uma teoria do efeito estético. Vol. 1. Trad. Johanes Kretshmer. São Paulo: Editora 34, 1996.

. O ato da leitura: uma teoria do efeito estético. Vol. 2. Trad. Johanes

Kretshmer. São Paulo: Editora 34, 1999.

JAUSS, H. R.; ISER, W. et al. A literatura e o leitor: textos de estética da recepção. Trad. Luiz Costa Lima. Rio de janeiro: Paz e Terra, 1979.

LAGO, Ângela. Tampinha. In: Historinhas pescadas. São Paulo: Moderna, 2001

PADILHA, P. R. Planejamento dialógico: como construir o projeto políticopedagógico da escola. Guia da escola cidadã 7. 2. ed. São Paulo: Cortez;

Instituto Paulo Freire, 2002.

ROJO, R. A prática de linguagem em sala de aula: praticando os PCN’s. 
Campinas, SP: Mercado de Letras, 2000.

SAMPAIO, M. L. P. A relação teoria-prática no ensino de leitura: o planejamento pedagógico como referência de análise. Dissertação (Mestrado). Natal: UFRN, 2002.

. A função mediadora do planejamento na aula de leitura. Tese (doutorado). Natal: UFRN, 2005.

. O conceito de leitura nos livros didáticos e suas implicações para formação do leitor. In: Amarilha, Marly (Org.) Educação e leitura: trajetórias de sentido. João Pessoa; Editora da UFPB-PPGEd/UFRN, 2003.

SMITH, F. Compreendendo a leitura: uma análise psicolingüística da leitura e do aprender a ler. Porto Alegre: Artes Médicas, 1991.

VIANNA, J. O. de A. Planejamento participativo na escola: um desafio para o educador. 2. ed. São Paulo: EPU, 2000.

VASCONCELLOS, C. dos S. Planejamento: projeto de ensino-aprendizagem e projeto político-pedagógico. 6. ed. São Paulo: Libertad, 1999.

VIGOTSKI, L. S. A formação social da mente. Trad. José Cipolla Neto, Luiz Silveira M. B e Solange C. Afeche. São Paulo: Martins Fontes, 1996.

[i] Agradecimento aos sujeitos da pesquisa e, em especial, a Prof ${ }^{\mathrm{a}}$ Rosa Leite da Costa pela revisão textual. 